\title{
Half way to real reform
}

\author{
Universities in Germany have undertaken overdue reform, but more \\ change is needed to fully tap their potential.
}

$\square$ ermany is the world's fourth largest investor in research and development, and its overall scientific impact suggests that much of the money is well spent. But a great deal of that impact comes from the 80 institutes of the Max Planck Society. The university sector is underperforming (see page 630).

The reasons for this can be traced back to the country's turbulent twentieth-century history and the ideologies that invaded the universities before and after the Second World War, on both sides of the Iron Curtain. By the 1990s, universities were overpopulated with students that they had not themselves selected, underfunded, and hide-bound by rules preventing them from competing with each other.

These problems have been recognized for a while, and other European countries may learn from Germany's response. Reforms implemented during the past few years have given the universities much more control over their own destinies, sending shockwaves through the academic landscape. For example, universities may now offer competitive salaries and conditions to selected researchers by transferring support from less productive colleagues.

To encourage institutions that are reluctant to make the most of their new freedoms, research organizations have launched competitions that highlight which universities are doing well and which badly. Perhaps the most influential has been the federal research ministry's Excellence Initiative, which selects a handful of élite universities.

All of this makes for a good start on university reform, but there is a long way to go. Visitors to German universities are unlikely to see, for example, the diversity of gender, age and nationality that they would encounter in a typical US research university. The number of female professors remains dismally small. New initiatives to increase the number of young professors have so far made only a small dent in academic demographics.

And Germany remains less attractive to young foreign scientists than it ought to be. The latest figures from the European Commission's Marie Curie programme, which funds young European Union (EU) researchers to work in a second EU country, show that only $11.5 \%$ choose to go to Germany - hardly changed from five years ago and still well below France (16\%) and the United Kingdom (32\%).
One reason for Britain's popularity is language - English is already widely spoken and a few years in an institution where it is the working language helps a scientific career. But the fact remains that German universities could do more to create a receptive environment for foreign students and staff.

It will be some time before the positive impact of the reforms undertaken so far shows up in statistics. In the meantime Germany needs to address a few extra problems that have been either caused or highlighted by the reforms themselves.

As efforts concentrate on building up a young faculty, the traditional position of the low-level academic, the Mittelbau, whose nearest equivalent is perhaps the assistant professor, is disappearing. The heavy teaching load that these people used to bear now falls on young professors who ought to be devoting themselves to research. This is a hard conflict to resolve, as the teaching is equally important - but recruitment must be broadened to address it.

"German universities could do more to create a receptive environment for foreign staff."

Additionally, many universities are still loath to appoint tenured professors from among their own junior staff. This principle was intended to avoid parochial appointments, but it has become less necessary in the current era of constant evaluation, where there is a natural pressure to appoint the best candidate. The rule often serves as an obstacle to young researchers seeking a route to tenure.

The universities will also benefit indirectly from the deal cut two years ago between federal and state governments, Germany's nonuniversity research institutes, and the DFG, the main grant-funding agency. In return for guaranteed 3\% annual budget increases until 2010 , these institutes are expected, among other things, to encourage greater collaboration with both industry and research universities.

This is a positive development for all concerned, giving institutes such as the Max Planck stable budgets and the universities better access to their resources. It is no coincidence that two of three universities selected by the Excellence Initiative had already developed unusually tight links with local Max Planck institutes.

\section{Bad execution}

\section{China won't achieve a tenable drug regulation policy by hanging public officials.}

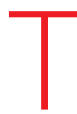
he sentencing to death of Zheng Xiaoyu, the former head of China's State Food and Drug Administration (SFDA), is a throwback to the nation's ugly past that will do little to further its professed goal of building a fair drug-regulation regime.
Zheng was sentenced to death in a Beijing court on 29 May on charges of accepting bribes, two years after he he was sacked from the drug regulator. Given the secrecy of China's judicial process, it is difficult to assess his guilt or innocence. But accusations involving the bribery of hundreds of officials have shadowed the agency for years. It is good that the Chinese government is facing up to the problem and taking public steps to clean up its drug-regulation process.

But hanging a man and vilifying him in state-controlled newspapers does not inspire confidence that China is building an effective drug-regulatory process. If the sentence is carried out, it is more likely 